\title{
Impact Assessments for Urban World Heritage: European Experiences under Scrutiny
}

\author{
Dennis Rodwell $^{a *}$ and Michael Turner ${ }^{b}$ \\ a Cultural Heritage and Sustainable Urban Development, Melrose, Scotland, UK \\ $b$ Graduate Program in Urban Design, Bezalel Academy of Arts and Design, Jerusalem, Israel \\ *Corresponding author: dennis@dennisrodwell.co.uk
}

\begin{abstract}
In the context of the broadening understanding of urban heritage, including the 2011 UNESCO Recommendation on the Historic Urban Landscape and related United Nations agendas such as the 2030 Sustainable Development Goals and the New Urban Agenda, this article questions the relevance of limited-focused impact assessments as a tool for the holistic management of complex urban sites in the $21^{\text {st }}$ century. The article identifies pitfalls in the use of such assessments, illustrating this principally with two cases in which retrospective assessments were undertaken post-inscription in an attempt to address conflicting interests: the visual impact study for Dresden Elbe Valley, inscribed on the World Heritage List in 2004 and delisted in 2009; and the three impact assessments for Liverpool Maritime Mercantile World Heritage Site, also inscribed in 2004, and placed on the List of World Heritage in Danger continuously since 2012. The article identifies critical missing elements that are inherent in discrete assessments, and provides indicators for practical tools with relevant applicability.
\end{abstract}

KEYWORDS assessment, reactive, proactive, World Heritage, Historic Urban Landscape, sustainable development

Received November 2, 2018; accepted December 10, 2018.

\section{Introduction ${ }^{1}$}

The past two decades have witnessed urbanisation at an unprecedented scale and generated a demand for rethinking the issues that arise through socio-economic transformations and the depletion of natural resources. The threats are not only in the environmental, social and economic fields but cultural in its widest sense, including the tangible heritage and legacies of our cities. This article examines the emergence of two distinct aspects of cultural heritage: the architectural monument and urban heritage, each with their diverse threats and requiring distinctive tools for management. The stand-alone methodology of heritage impact assessment, well suited for the monument, when applied to urban complexities and appended independently to environmental impact assessment, has not addressed the interconnected composite urban relationships. Heritage impact assessment methodology enshrined the reactive approach to large-scale development projects, whereas more all-encompassing and proactive tools, as strategic impact assessment, are needed to address these issues and provide for true community debate and public participation.

Our cases of Dresden Elbe Valley and LiverpoolMaritime Mercantile City are extreme examples of World Heritage properties, with the former being delisted in 2009 and the latter confirmed on the List of World Heritage in Danger continuously since 2012. In the case of Dresden, they illustrate the application of a limited-focus visual impact study for the proposed Waldschlößchen Bridge crossing of the river Elbe, which ignored both the environmental, economic and transport management of the city as well as alternative and less obtrusive design options for the bridge itself. In the case of Liverpool, three inconsistent impact assessments for the major Liverpool Waters development project along the waterfront immediately to the north of the city centre, founded on-or in one case largely under-played-visual impacts on the World Heritage Site whilst ignoring the potentially significant socio-economic impacts and relationships across the wider city. 


\section{Background and Context}

\section{$20^{\text {th }}$ Century Timeline}

In the early part of the last century, the canonical texts on cultural heritage focused on the preservation of monuments and sites, and were often embedded in the institutional frameworks of archaeology, historic buildings and memorials.

Concurrently, the issue of urbanism came to the fore in the Athens Charter of 1933 (Le Corbusier 1955, 1973; Erder 1986), produced as a result of the Fourth International Congress of Modern Architecture (CIAM). Acknowledging 'The Historic Heritage of Cities', Article 65 opens: 'Architectural assets must be protected, whether found in isolated buildings or urban aggregations. The life of a city is a continuous event that is expressed through centuries by material works-layouts and building structures-which form the city's personality, and from which its soul gradually emanates. The socio-economic events of the 1930s coupled with its first publication in 1943 made the Charter especially relevant to the continuing activities of the CIAM after World War II. The architects of the CIAM did not, however, engage with the conservation movement, which continued in a parallel track.

The post-war period was characterised by rapid development and threats to the destruction of individual monuments and sites, coupled with threats to the urban landscape and socio-cultural values of cities. The former demanded a reaction to projects; the latter, to the management of urban processes. The threats, although with similar origins, had dramatically different dimensions in their application, with a greatly increased level of complexity in the urban sphere.

The year 1972 constituted a turning point, with the Stockholm Declaration at the United Nations Conference on the Human Environment (United Nations 1972) and the UNESCO adoption of the World Heritage Convention (UNESCO 1972). Although these two documents had lives of their own, the interconnections between the cultural heritage of 'monuments, groups of buildings and sites' and the natural environment was inherent, if not manifest, in the crafting of their texts.

\section{Genesis and Critiques of Impact Assessment Methodologies}

The Stockholm Declaration came in the wake of growing environmental concerns, the establishment in 1970 of the United States of America's Environmental Protection Agency (EPA 1992), and its adoption of environmental impact assessment which were introduced through the enactment of the National Environmental Policy Act of 1969. This evolved from the natural science disciplines, particularly in the ecology field. Early writers such as Ian McHarg referred to the need to 'design with nature' (McHarg 1969), and environmental impact assessment was seen as a way in which development projects could be designed with the aim of mitigating the worst effects on the environment. By the time that the term 'sustainable development' became popularised in the Brundtland Report (WCED 1987)' , environmental impact assessment was already a well-established instrument that was recruited for a wider and more comprehensive need.

With the complementary social and economic pillars of sustainability, however, environmental impact assessment was considered as a reactive tool when applied at the project level. The emerging strategic environmental assessment was conceived as a proactive multi-disciplinary tool, considering wider strategic impacts and encouraging the participation of the spectrum of stakeholders. With this comprehensiveness, associated disciplines became involved, and it is now generally considered that the process of impact assessment (in a generic sense) is not just about the immediate outcomes or the statement produced, but the greater value of the process in stimulating stakeholder dialogue (Sheate and Partidário 2010). Although the term 'environment' has become all-inclusive, Partidário in an earlier article notes that 'if we want to be systematic about the identification and assessment of impacts likely to result from strategic options ... then we need an impact assessment tool that is designed to operate in a strategic context. We need strategic impact assessment' (Partidário 2005). With the declaration of the specificity of 'heritage' and other planning and design components there is a clear need to adopt the generic term ${ }^{3}$.

Meanwhile, the 1964 Venice Charter had continued the monument tradition, albeit with the recognition that the 'historic monument embraces not only the single architectural work but also the urban or rural setting in which is found the evidence of a particular civilisation, a significant development or an historic event' (ICOMOS 1964). The debate on setting was compounded with context, culminating in the ICOMOS Xian Declaration on the Conservation of the Setting of Heritage Structures, Sites and Areas (ICOMOS 2005).

Significantly, also in 2005, at the height of the debate on the Vienna Memorandum (see below), Professor Andrej Tomaszewski, architect and art historian, Director-General of ICCROM from 1988 to 1992, subsequently Conservator-General of the Republic of Poland, and as President 
of the Polish National Committee of ICOMOS, wrote (Tomaszewski 2005):

The Venice Charter, though it was based on the Athens resolutions (ICOMOS 2004a), concentrates entirely on the microscale of individual monuments. But by ignoring the problem of the urban and landscape macro scale, it can be regarded as a step backwards. The recognition by ICOMOS of the Venice Charter as the 'Ten Commandments' of conservation led to several decades of stagnation in the theorising about the protection of cultural property. Instead of theoretical studies, we saw the creation of increasing numbers of 'Charters' of varying intellectual value, consisting of bare desiderata, presented to be believed-in and applied, rather than to arouse scientific methodological reflection. Doctrine replaces Philosophy and Theory. Only in the last fifteen years, due to impulses from Asia (a pluralistic understanding of the concept of authenticity) and Africa (regarding intangible values), has conservation been aroused from its intellectual torpor. The acceptance of the dichotomy, 'monuments and sites-their setting' as the topic of our symposium ${ }^{4}$, is artificial and anachronistic. That, which was until recently just the troublesome setting of an historical monument, today is also protected cultural property (e.g., historic industry). It is currently necessary to conduct a thorough realignment of our concepts, and in our investigative methodology to pass from induction to deduction. The main aim of the protection of cultural property becomes therefore not a monument and site in their setting, but a unit of a cultural/natural landscape with its monuments and sites [Tomaszewski's emphasis]. Operating in the macroscale allows us to form a mutual partnership with the natural environmental conservation movement permitting the creation together of a common 'blue-green ecological programme'.

In this, Tomaszewski fairly and squarely called upon heritage professionals to recognise that the traditional tools for architectural and archaeological preservation are not suitable for the conservation of urban heritage. This was taken further in the ICOMOS Ename Charter (ICOMOS 2008), which determined as Principle 3, Context and Setting, that 'the interpretation of cultural heritage sites should relate to their wider social, cultural, historical, and natural contexts and settings'.

With the definitions of natural contexts and settings, the two cultural components-the architectural monument and urban heritage-finally came of age as distinct but interrelated parts of this mosaic. Although, the concept and use of 'environment', in all spheres by IUCN, became the accepted coinage, there was no effort by ICOMOS to consider the merging of these concepts and terms. The all-embracing 'nature' with its planning and design approaches reached out to 'culture' with Urban Biospheres and Urban Protected Areas, without any reciprocity.

This is changing with the greater acceptance of sustainable development ${ }^{5}$, the 2011 UNESCO Recommendation on the Historic Urban Landscape (UNESCO 2011) and the 2016 UN-Habitat New Urban Agenda (United Nations 2016), and the evolution of a more comprehensive and proactive attitude to the role of cultural heritage. For example, the 2006 Sustainable Development Act adopted by the province of Québec (Québec Government 2006), incorporates cultural heritage in the core principles rather than its usual consideration far down the chain in environmental impact assessment procedures. Its Clause $6(\mathrm{k})$ reads:

Protection of cultural heritage: The cultural heritage, made up of property, sites, landscapes, traditions and knowledge, reflects the identity of a society. It passes on the values of a society from generation to generation, and the preservation of this heritage fosters the sustainability of development. Cultural heritage components must be identified, protected and enhanced, taking their intrinsic rarity and fragility into account.

\section{Integrated Conservation}

This more integrative approach in which heritage is treated as a component part of the environment, is not only effective, but also deals with 'assessment fatigue' whereby planning processes are bogged down in multiple assessment and bureaucratic reporting. The European Union Review of the Environmental Impact Assessment Directive now guides Member States to simplify their different environmental assessment procedures (European Commission 2014a). Its Article 3 notes that the principles of the assessment of environmental effects should be harmonised, in particular with reference to the projects which should be subject to assessment, but clearly takes on board 'material assets, cultural heritage and the landscape ${ }^{6}$. In 2014, the European Commission defined cultural heritage as including 'natural, built and archaeological sites, museums; monuments, artworks; historic cities; literary, musical, and audio-visual works, and the knowledge, practices and traditions of European citizens' 
(European Commission 2014b). Additionally, the European Union's 2010 Toledo Declaration represented the long-term challenges facing existing cities, including a 'more sustainable and socially inclusive model in the whole built environment and in all the social fabrics of the existing city' (European Union 2010).

The major problem, however, was and continues to be the lack of data, harmonisation of it, and awareness of the essence of the interdependence of heritage fabric and the multi-faceted socio-economic issues that condition urban heritage (Ripp and Rodwell 2015, 2016). This, despite the Council of Europe's 1975 European Charter, which introduced the concept of integrated conservation (Council of Europe 1975), and the 1976 UNESCO Nairobi Recommendation, which articulated the need to integrate historic areas into 'the life of contemporary society [as] a basic factor in town-planning and land development' (UNESCO 1976). Subsequently, in 1994, ICCROM initiated the Integrated Territorial and Urban Conservation Programme (Jokilehto 1999), which offered a training programme that developed scientific concepts related to integrated urban conservation and anticipated the UNESCO Historic Urban Landscape approach.

\section{$21^{\text {st }}$ Century Timeline}

In the event, it was not until 2005 that the debate on urban heritage established momentum, with the UNESCO Vienna Memorandum (UNESCO 2005). Although initiated within the World Heritage Centre, this evolved as a UNESCO standard setting tool in 2011 with the adoption of the Recommendation on the Historic Urban Landscape (UNESCO 2011). This recommendation emphasised the holistic approach, building on the body of knowledge accumulated to date.

Mention should also be made of the various European Union initiatives and programmes, especially the 2004 SUIT (acronym for Sustainable development of Urban historical areas through an active Integration within Towns) (European Commission 2004); and, in 2008, the URBACT HerO (Heritage as Opportunity) network, which aimed 'to develop integrated and innovative management strategies for historic urban landscapes' (URBACT 2012).

The years since 2015 have provided a swathe of texts that will require further integration and further distance the capacities of stand-alone assessments. These include the United Nations Office for Disaster Risk Reduction Sendai Framework (UNISDR 2015) and Resilient Cities Campaign (UNISDR 2017a) with its 'Ten Essentials for Resilient Cities' (UNISDR 2017b), and the United Nations
2030 Sustainable Development Goals (United Nations 2016b). With these in mind, UNESCO prepared Culture: Urban Future-A Global Report on Culture for Sustainable Urban Development (UNESCO 2016), and the United Nations Conference on Housing and Sustainable Urban Development (Habitat III) adopted the New Urban Agenda (United Nations 2016a). This was completed with the Paris Agreement of the United Nations Framework Convention on Climate Change (United Nations 2017).

This has firmly settled the broadening of heritage from monuments to include living cities, and the evolution of sustainable development to address the wider understanding of the environment.

\section{What Are the Challenges That We Are Addressing?}

This up-scaling of recognition of the challenges facing urban heritage as opposed to monuments and sites demands relevant tools and appropriate mechanisms for assessment.

It was the World Heritage Committee that looked to its Advisory Body, ICOMOS, in 2008 to assist in identifying the threats to many urban properties from various forms of large-scale developments (UNESCO 2008a). As presented in the 2011 ICOMOS report Guidance on Heritage Impact Assessments for Cultural World Heritage Properties, these developments included 'roads, bridges, tall buildings, "box" buildings (e.g., malls), inappropriate, acontextual or insensitive developments, renewals, demolitions and new infrastructure typologies like wind farms, as well as land-use policy changes and large scale urban frameworks' (ICOMOS 2011a). The 2011 Guidance was developed following an undocumented internal workshop organised by ICOMOS in Paris in September 2009 and noted the inadequacies of environmental impact assessment for the holistic evaluation of heritage attributes:

Where formal evaluations are undertaken, many of these make use of procedures for environmental impact assessment (EIA). Whilst there is merit at looking at the experience of EIA, this is not likely to be immediately useful without some adaptation. EIA frequently disaggregates all the possible cultural heritage attributes and assesses impact on them separately, through discrete receptors such as protected buildings, archaeological sites, and specified view-points with their view cones, without applying the lens of OUV [Outstanding Universal Value] to the overall ensemble of attributes. A more global approach to the site is required, one directly linked to the expression of the site's 
OUV. EIA therefore often produces disappointing results when applied to cultural World Heritage properties as the assessment of impacts is not clearly and directly tied to the attributes of OUV [authors' italics]. Cumulative impacts and incremental changes (adverse) may also more easily pass undetected (ICOMOS 2011a).

The 'disappointing results' generated a silo approach, by having to 'respond to the needs of World Heritage sites, through considering them as discrete entities'. This was compounded by noting that 'an HIA undertaken as part of an EIA in these circumstances is not additional to normal EIA requirements, but uses a different methodology [authors' italics] which clearly focuses on OUV and attributes that convey that OUV' (ICOMOS 2011a). While the importance of sectorial evaluation is important, the development of 'different methodologies' is confusing for the decision-making processes. At a training workshop at the World Heritage Institute of Training and Research for the Asia and the Pacific Region under the auspices of UNECSO (WHITRAP) at Tongji University, the International Association of Impact Assessment is quoted:

(Cultural) Heritage Impact Assessment is a process of identifying, predicting, evaluating and communicating the probable effects of a current or proposed development policy or action on the heritage values (including Outstanding Universal Value in the case of World Heritage Properties), cultural life, institutions and resources of communities, then integrating the findings and conclusions into the planning and decision making process, with a view to mitigating adverse impacts and enhancing positive outcomes (WHITRAP 2012).

Heritage impact assessment appears to have been formulated for application to monuments and sites and by professionals focusing on them. The need to extend the heritage assessment beyond the single monument into the living city has highlighted the necessity of evaluating the dynamics of change, and the role of continuity in the generation of planning alternatives together with the management of sectorial decision-making processes (Ripp and Rodwell 2016). These evolving planning processes were previously accompanied by a lack of transparency that is now being addressed through community empowerment, demanding a more up-front and proactive tool.

With the greater application of environmental and social impact assessments, including approaches to the Sustainable Development Goals dealing with poverty, crime and exclusiveness, the links to cultural heritage have become more complex, especially in relationships to urban renewal and associated gentrification. Target 11.4 clearly links heritage as a means to an end by 'strengthen[ing] efforts to protect and safeguard the world's cultural and natural heritage' to achieve the goal of making our 'cities [and human settlements] inclusive, safe, resilient and sustainable' (United Nations 2016). With accelerated urbanisation and social transformations, changing value judgments have made assessment even more volatile and the need for an integrative approach essential.

\section{State of Conservation-Threats}

Impact assessment needs to relate to the threats identified to the values of our urban environment and resulting indicators. It is a means to an end, and needs to be seen in its reactive environmental impact assessment mode and the proactive and comprehensive strategic impact assessment mode; furthermore, to relate to the impacts on the monument as an object and the living city as a process. The 2011 UNESCO Recommendation on the Historic Urban Landscape, UN 2030 Sustainable Development Goals, UN-Habitat New Urban Agenda, United Nations International Strategy for Disaster Reduction (UNISDR) Resilient Cities, and the many European Union directives have yet to provide a coherent monitoring platform as they gather information on evolving quantitative indicators.

1. Development and infrastructure:
Buildings and development
Transportation infrastructure
Services infrastructures
Pollution
Physical resource extraction
2. Other human activities:
Social/cultural uses of heritage
Biological resource use/modification
Trans-located and genetically modified species
3. Natural events and disasters:
Local conditions affecting physical fabric
Climate change and severe weather events
Sudden ecological or geological events
Invasive/alien species or hyper-abundant species
4. Management and legal issues:
Management and institutional factors
5. Other issues
(such as risk of or collapse or deterioration due to age of
building, problem of stability of the structures, etc...)

Box 1 Factors threatening the Outstanding Universal Value of World Heriatge (Source: UNESCO 2018). 
Table 1 Top threats to World Heritage Sites in the urban context (Source: the author).

\begin{tabular}{|l|c|}
\hline $\begin{array}{l}\text { Factors affecting the Outstanding } \\
\text { Universal Value }\end{array}$ & $\begin{array}{l}\text { Percentage of } \\
\text { properties affected }\end{array}$ \\
\hline $\begin{array}{l}\text { Management and institutional factors } \\
\text { (governance) }\end{array}$ & 70.8 \\
\hline Buildings and development & 43.1 \\
\hline Other human activities & 37.5 \\
\hline Social/culture use of heritage & 27.8 \\
\hline Transportation infrastructure & 23.6 \\
\hline
\end{tabular}

Over the years the World Heritage Committee and its State of Conservation Reporting has provided a consistent, if simplistic, methodology and understanding of the threats to heritage over time; many important lessons, however, can be taken from these reports. The standardised list affecting the World Heritage properties designed during the revision of the periodic reporting questionnaire (UNESCO 2008b), consists of 14 factors in five primary groups of threats, each encompassing a number of secondary factors (Box 1).

Being a list that bridges culture and nature, there is a need to highlight and isolate the factors affecting urban heritage and categorise the 'other issues' as structural stability, socio-economic threats and risk preparedness. The top five threats are considered within the urban context, with lack of management and institutional factors including governance representing the core issue that needs to be addressed. The analysis of the first reporting years undertaken by the authors of this article gives the following results (Table 1 ).

The challenges to the environmental degradation of our cities have been well stated in the UN-Habitat New Urban Agenda (United Nations 2016a), which acknowledges the role of culture in paragraphs 10, 80 and 124 with support for adaptation planning processes and impact assessments:

10. The New Urban Agenda acknowledges that culture and cultural diversity are sources of enrichment for humankind and provides an important contribution to the sustainable development of cities, human settlements, and citizens, empowering them to play an active and unique role in development initiatives; and further recognises that culture should be taken into account in the promotion and implementation of new sustainable consumption and production patterns that contribute to the responsible use of resources and address the adverse impact of climate change.
80. We commit to support the medium to long-term adaptation planning process, as well as city-level climate vulnerability and impact assessments to inform adaptation plans, policies, programmes, and actions that build resilience of urban inhabitants, including through the use of ecosystem-based adaptation.

124. We will include culture as a priority component of urban plans and strategies in the adoption of planning instruments, including master plans, zoning guidelines, building codes, coastal management policies, and strategic development policies that safeguard a diverse range of tangible and intangible cultural heritage and landscapes, and will protect them from potential disruptive impacts of urban development. Adopting target 11.4 of the Sustainable Development Goals sees the safeguarding of urban heritage as a component part to the achieving of sustainable development rather than being diametrically opposed to development (United Nations 2016a).

\section{What Are the Tools to Address These Challenges?}

We cannot solve the problems of tomorrow with the tools of yesterday. One of our biggest opportunities is in the digital revolution. Our capacity for data collection has progressed in leaps and bounds and includes space tracking and the understanding of incremental changes that have hitherto been hidden. The UNESCO Category 2 Centre on Space Technologies for Natural and Cultural Heritage is applying space technologies to the monitoring and conservation of World Heritage properties through a Digital Earth Platform, with capabilities for data storage, information analysis and simulation research currently covering 70\% of Asia. The European Research Group for Earth Observation at the Heidelberg University of Education is specialising in the analysis and evaluation of land use change as well as the acquisition and modelling of diverse spatial information.

While heritage impact assessment may be relevant to the era of monuments and sites, it is not a suitable tool for addressing today's agendas that are encompassed within cities and urban heritage. The 2015 ICOMOS review of the 2011 Guidance on Heritage Impact Assessments for Cultural World Heritage Properties, indicated that of the 31 cases researched, 'only three conclusions of HIA-reports were subsequently mentioned in the SoC [State of Conservation] reports, of which two HIAs seem to conclude that the project has no impact on the OUV [Outstanding Universal Value]. Only one of them suggested mitigation measures' (ICOMOS 2015). 

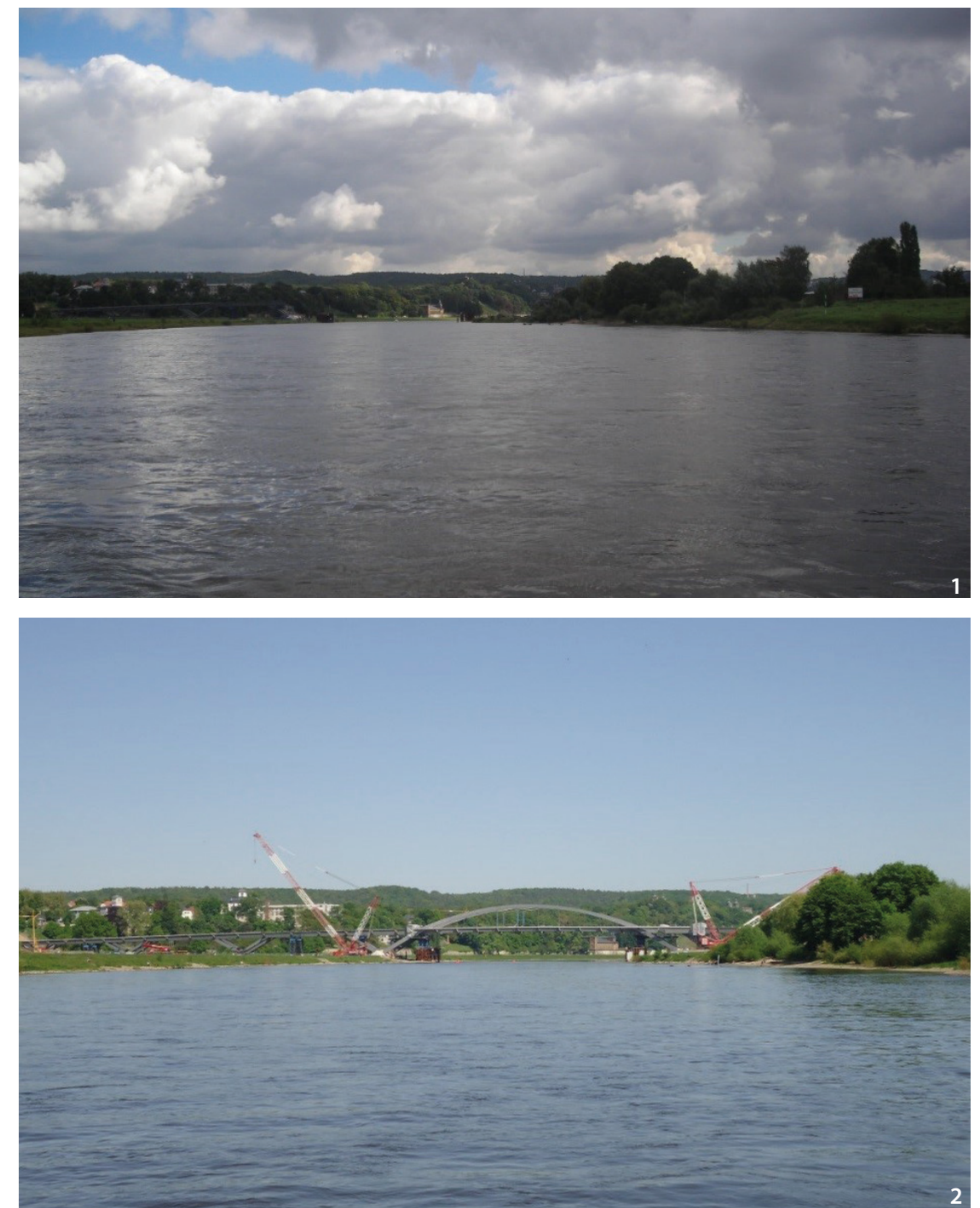

Figure 1 Dresden Elbe Valley, 2008: View looking eastwards from the city centre along the course of the Elbe to the site of the Waldschlößchen Bridge crossing. (Source: Perrine Deruelles).

Figure 2 Dresden Elbe Valley, 2011: The same view showing the Waldschlößchen Bridge nearing completion. From this viewpoint the bridge is clearly visible, notably the superstructure above the carriageway; a design feature rather than a structural necessity. (Source: Bénédicte Gaillard).

The starting point must be to assess the intervention options that are facing our cities. These include contextual strategies that embrace the city-wide dynamics of expansion and contraction, and policies for, inter alia, redevelopment or refit, reconstruction or adaptation, and renewal or infill. Alternative interventions demand different tools for evaluation. The evaluation process needs to be dynamic and cross-referenced, with matrices linking interventions with values, people with systems, and causes with effects.

There is no doubt that we have to change the shape of the box' both spatially and conceptually, with the assessment including the 'broader context' in all meanings. The Recommendation on the Historic Urban Landscape proposes four tools which should be harnessed for both pro-action and re-action to new interventions in the city (UNESCO 2011). This approach implies the application of a range of traditional and innovative tools adapted to local contexts. Some of these tools, which need to be developed as part of the process involving the different stakeholders, might include: (a) Civic engagement tools; (b) Knowledge and planning tools; (c) Regulatory systems and (d) Financial tools.

To the tools, should be added the recommendations on (V) Capacity-building, research, information and communication, and (VI) International cooperation.

\section{Pitfalls in the Use of Limited-Aspect Impact Assessments and Challenges to the World Heritage Process}

This section addresses two examples of World Heritage properties that were inscribed in 2004, and where the World Heritage Committee had accepted limited-aspect impact assessments that were undertaken retrospectively, after key decisions had already been taken concerning the projects on which they focused. In both cases, the 

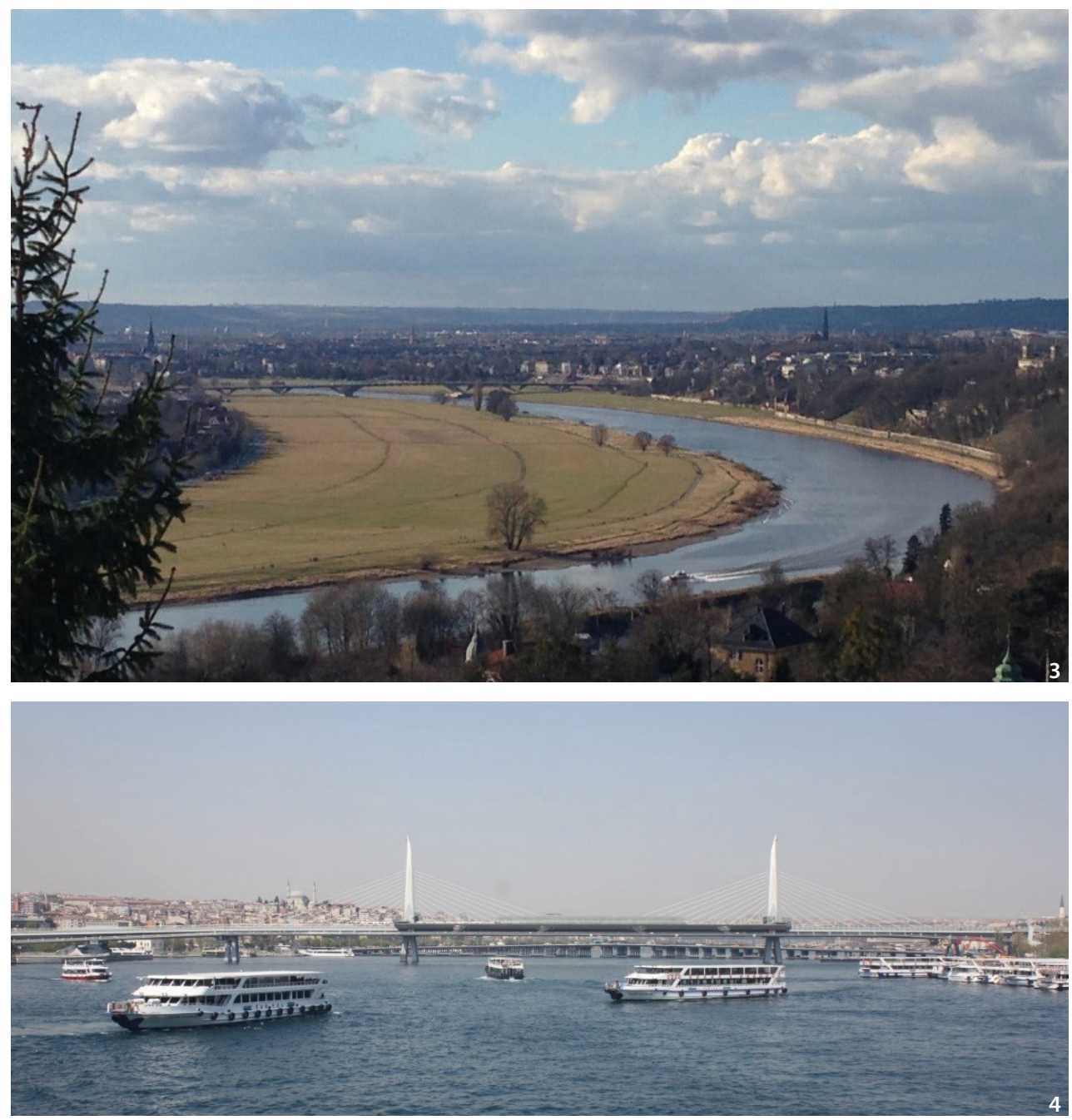

Figure 3 Dresden Elbe Valley, 2014: View looking west from the top of the cable railway in Loschwitz (Dresden) along the course of the Elbe Valley towards Dresden city centre, with the completed Waldschlößchen Bridge in the middle distance (Source: Bénédicte Gaillard). Figure 4 Historic Areas of Istanbul, 2017: View along the Haliç (Golden Horn) of the completed new bridge and "its towering cable-stay structure (Source: Dennis Rodwell).

narrow heritage view taken in confronting the threats to the Outstanding Universal Value did not allow for alternative more comprehensive urban solutions. This is further strengthened by an analytical critique of the ICOMOS Heritage Impact Assessment Guidelines where it was seen that their assumptions 'derive from the "preservation" discourse in heritage management, rather than from the “conservation" or "heritage planning” discourses' (Patiwael, Groote and Vanclay 2018).

\section{Dresden Elbe Valley, Federal Republic of Germany}

The case of Dresden Elbe Valley, inscribed as a cultural landscape and the only cultural heritage site to be delisted to date, is regularly cited as an exemplar of the strength of the World Heritage Convention and its associated processes. This view merits closer examination (Gaillard and Rodwell 2015).

A key element of the World Heritage process that is rarely admitted (Ringbeck and Rössler 2011), concerns the ICOMOS evaluation report upon which the 2004 inscription was founded ICOMOS (2004b). A vital passage in that report both acknowledged and approved the construction of the Waldschlößchen Bridge, the intervention that led directly to the de-listing: 'Its design results from an international competition. The profile has been kept slender and low in order to reduce impact on landscape.' (ICOMOS 2004b) Subsequent heated controversy embraced the federal government and Länder (regions), citizens and the media and, ironically, intervention by the then President of ICOMOS which ignored the 2004 ICOMOS evaluation report, and led to a retrospective, limited-aspect visual impact study carried out by the Institute of Urban Design and Regional Planning of the Technical University of Aachen (RWTH Aachen University) which resulted in 2006 to the placing of the site on the List of World Heritage in Danger and its de-listing in 2009.

This visual impact study only considered the project that had been admitted in the State Party's nomination document and endorsed in the ICOMOS evaluation report. From a structural engineering perspective, the 
arched super-structure to the bridge, rising above carriageway level, was a design option, not a requirement. The visual impact study did not address the question of an alternative structural design for the bridge; for example, repositioning the arch below the carriageway, thereby echoing the design of the several existing river crossings and minimising the new bridge's visual impact (Figure 1-3).

Irrespective of the merits or otherwise of the siting and design of the Waldschlößchen Bridge or indeed any new intervention into a World Heritage property, this case has several lessons to offer, of which three suffice here:

- First: within the framework of a Convention that is ratified worldwide today by 193 States Parties, there is an elemental prerequisite for certainty, clarity, and consistency-the basis for effective protection. Without these, the World Heritage system flounders;

- Second: any heritage impact assessment, visual impact study or other, should be proactive, before commitments are made to formulate and implement interventions. The appropriate form for proactive assessment would be a strategic impact assessment;

- Third: sectorial impact assessments, as a limited-focus reaction to specific threats, denies the opportunity to assess the need for an intervention, alternative approaches to meet that need, and wider impacts-be they environmental, social, cultural, economic or any other.

This case of the Waldschlößchen Bridge has many parallels with the contemporaneous project for a new bridge across the Haliç (Golden Horn), whose potentially adverse visual impact on the Historic Areas of Istanbul World
Heritage Site came to the attention of successive sessions of the World Heritage Committee from 2006 onwards, concern being focused on its towering cable-stay structure ... on the property and its setting and on the Süleymaniye Mosque in particular' (UNESCO 2009) (Figure 4).

Again, the bridge was designed to be seen, with a super-structure that did not echo the horizontal lines of the neighbouring Galata Bridge. In this case, however, minor adjustments to the detailed configuration and colour were deemed sufficient to satisfy the World Heritage Committee. It is probable that the unsatisfactory precedent of Dresden Elbe Valley acted as a deterrent (subliminal or otherwise) to placing the Historic Areas of Istanbul on the List of World Heritage in Danger or delisting.

\section{Liverpool-Maritime Mercantile City, United Kingdom}

The case of Liverpool-Maritime Mercantile City has parallels with Dresden, and implicates the full complexity of urban issues (Gaillard and Rodwell 2015). In this case, a major discrepancy arose between the nomination document and the ICOMOS evaluation report ICOMOS (2014b). The former emphasised the importance of the city's urban landscape, especially from the River Mersey waterfront; the latter deleted urban landscape from the State Party's draft text for the justification of Outstanding Universal Value, an omission that was repeated in the final version, the property being considered as 'a group of buildings. This severely curtailed the terms of reference for the first, 2006, UNESCO-ICOMOS reactive monitoring

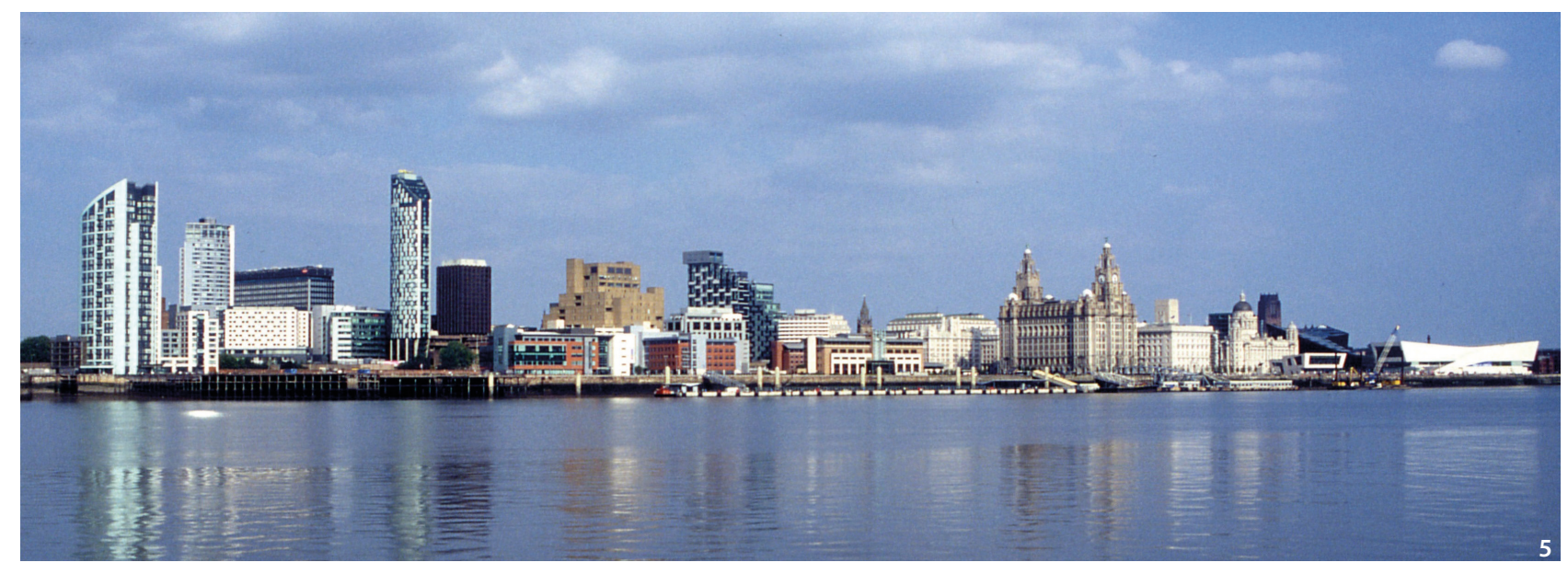

Figure 5 Liverpool Maritime Mercantile City, 2011: Panorama of the Merseyside waterfront from the seaward north-west. It was a core theme of the 2003 nomination document that the surviving urban landscape testifies to the historical role of Liverpool as a great port city and defines its 'tangible authenticity'. The focal point, the Pier Head Group, popularly known as the Three Graces, 'form a dramatic manifestation of Liverpool's historical significance ... [whose] vast scale ... allows them to dominate the waterfront when approaching by ship' (Liverpool City Council 2003). (Centre right: the Pier Head Group. Far right, the Museum of Liverpool, completed 2011. Left hand side: tall buildings constructed post-inscription.) (Source: Dennis Rodwell). 

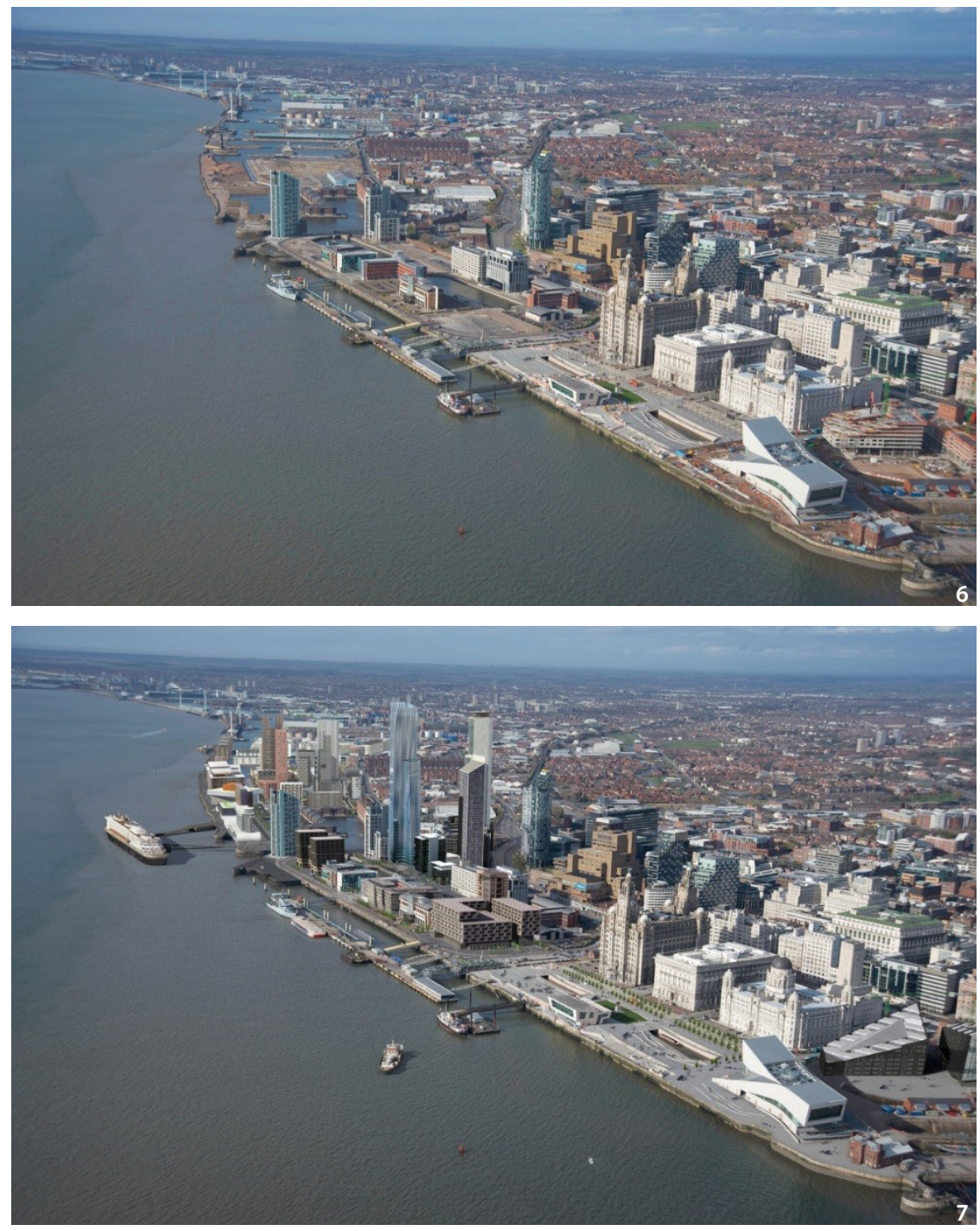

Figure 6 Liverpool Maritime Mercantile City, 2009: Aerial view of the Pier Head group looking northwards across the site of Liverpool Waters (Source: www.ruststudios.co.uk).

Figure 7 Liverpool Maritime Mercantile City: A 2014 visualisation of the same view showing the proposed development of Liverpool Waters (Source: www.ruststudios.co.uk).

mission (UNESCO 2006) - one year after the interim 2005 Vienna Memorandum, but still five years before the 2011 Recommendation of the Historic Urban Landscape.

In the lead up to the granting by Liverpool City Council of planning permission for the controversial Liverpool Waters in March 2012 - the major new city-scale development proposed for land within and beyond the seaward waterfront of the World Heritage property and buffer zone-three impact assessments were prepared: for English Heritage (Bond 2012), the national heritage agency and adviser to the State Party (through the Department for Culture, Media and Sport), which opposed Liverpool Waters, primarily on visual grounds; Liverpool City Council (Hinchliffe and Burns 2012), the local authority that supported and granted outline planning permission for Liverpool Waters, a permission that was subsequently approved by the state party (through another arm of the UK government, the Department for Communities and
Local Government); and by the developer for Liverpool Waters, Peel Holdings, which also, self-evidently, endorsed the project (De Figueiredo 2011) (Figure 5-7).

These three limited-aspect reactive impact assessments, each coming from governmental and private sector interests with pre-determined starting points, disclose three essentially distinct interpretations of the Outstanding Universal Value of the site. More serious, the limitations of impact assessment methodology as well as the World Heritage system in its singular focus on Outstanding Universal Value coupled with the varied interpretation of it postinscription, meant that the decision to place the property on the List of World Heritage in Danger, and the threat to delist at subsequent sessions of the World Heritage Committee (UNESCO 2017):

- Has not been related to any consideration of the impacts of Liverpool Waters as a projected major new layer for the city, whether in the context of the 
forecasted numerical stability in the city's population, the extent of vacancy of properties in the historic centre, waterfront as well as addressing longstanding issues of urban poverty deprivation in the city;

- Has not evaluated the investment impact that Liverpool Waters is expected to have in syphoning investment away from the World Heritage property (Rodwell 2014, 2015);

- Has been focused on the proposed 'super-towers' (including a $192 \mathrm{~m}$ tall 'Shanghai Tower') and the view that the historical authenticity of the World Heritage property would thereby be 'irreversibly damaged'; and, in short,

- Does not relate holistically to the threats on the Outstanding Universal Value which may be identified through the 2011 UNESCO Recommendation on the Historic Urban Landscape.

\section{Conclusion}

The need for specialised knowledge to assess impacts of and on urban heritage does not necessitate unique methodologies for evaluation within the planning process. On the contrary, the studies show that only by putting urban heritage in the broader context will the benefits of culture be appreciated. Decision-making on the choice of interventions in an isolated monument or site cannot be compared to the complexities of the urban context.

Sectorial decisions in the field of heritage will, in many instances, bring about conflict in the planning process and polarisation between conservation and development. The approach for 'culture as an enabler for sustainable development' demands integrative thinking directed at achieving a better balance in the management of natural resources in and around our cities. This, together with resilience and social justice, will complete the achievement of the UN Sustainable Development Goal 11, Target 11.4, strengthening 'efforts to protect and safeguard the world's cultural and natural heritage' as a major contributor to 'make cities and human settlements inclusive, safe, resilient and sustainable'.

While impact assessment is a reactive tool, there is an urgent need to generate mechanisms that may integrate heritage values within the proactive realm of urban planning and design. In reviewing the 2011 ICOMOS 'Guidance on Heritage Impact Assessments for Cultural World Heritage Properties', the Summary Report of 2015 made reference to further research to 'explore ways to ensure that HIAs are embedded in the international legislative frameworks for environmental impact assessments, and promote understanding as to how HIAs relate to EIAs' This was seen as particularly important within Europe, where a coordination between 'EIA, SIA and HIA process and operational specifications for HIA within this framework ... would be beneficial for an improved and expanded application of HIAs'. A more comprehensive approach would be to generate the concept of impact assessment together with a more proactive and policy-orientated tool in the form of strategic impact assessments. The inclusion of heritage values as an inherent part of environment is a step in the right direction, as the environmental impact assessment processes accepted around the world includes three important component parts: scoping; the generating of alternatives; and stakeholder participation/ consultation. These are essential elements in project evaluation. Urban heritage experts need to engage specifically in these stages of the evaluation and input these values as part of the inter-disciplinary team.

The need to prepare a desired State of Conservation for the removal of a property from the List of World Heritage in Danger and a set of corrective measures does not always allow for comprehending the urban causes and effects and for engaging the wider issues in resolving the threats to the Outstanding Universal Value.

The role of the UNESCO Recommendation on the Historic Urban Landscape cannot be underestimated in becoming a proactive tool for ensuring that 'urban heritage, including its tangible and intangible components, will constitute a key resource in enhancing the liveability of urban areas, and foster economic development and social cohesion in a changing global environment' (UNESCO 2011). This recommendation will need to be dovetailed into the New Urban Agenda linking culture and nature and the new approaches of ICOMOS and IUCN to the UN Sustainable Development Goals.

\section{Notes}

1. Abbreviations and acronyms: Without going into the history of neologisms, abbreviations and acronyms can create ambiguities and serve as barriers rather than aids to communication, especially in fields that anticipate inter-disciplinary engagement and cooperation. HIA, for example, commonly used in the cultural heritage field to signify Heritage Impact Assessment, denotes Health Impact Assessment in the medical field. EIA, SEA and HUL also invite confusion. For this reason, and with the exception of unambiguous examples such as UNESCO and ICOMOS, all terms are spelled out in full in this article except where quoted from cited texts. 
2. The 1987 Brundtland Report highlighted the conclusion that current patterns of resource consumption and environmental degradation cannot continue, and that economic development must adapt to the planet's ecological limits. It encapsulated the three fundamental components of sustainable development as environment, economy and society.

3. This has been stated by the International Association for Impact Assessment in their mission by promoting 'the application of integrated and participatory approaches to impact assessment, ...' and believing that 'the assessment of the environmental, social, economic, cultural, and health implications to be a critical contribution to sound decision-making processes, and to equitable and sustainable development' (IAIA 2009).

4. This refers to the $15^{\text {th }}$ ICOMOS General Assembly and International Symposium, 'Monuments and Sites in Their Setting-Conserving Cultural Heritage in Changing Townscapes and Landscapes', held at Xi'an, China, October 2005 (ICOMOS 2005).

5. ICOMOS in 2011 passed The Paris Declaration 'On Heritage as a Driver of Development' (ICOMOS 2011b), subsequently initiated a Task Force to react to the debate on the Sustainable Development Goals, and in 2016 adopted the ICOMOS Concept Note on 'Cultural Heritage, the UN Sustainable Development Goals and the New Urban Agenda' (ICOMOS 2017). This note argues for a 'positive integration of culture and cultural heritage into urban development plans and policies as a way to enhance sustainability of urban areas through heritage, in the context of the newly adopted Agenda 2030 ...'

6. Directive 2011/92/EU of the European Parliament and of the Council of 13 December 2011 on the assessment of the effects of certain public and private projects on the environment (codification) (OJ L 26, 28.1.2012, p. 1) As amended by: Directive 2014/52/EU of the European Parliament and of the Council of 16 April 2014(OJL 124, 25.4.2014, p. 1)

\section{References}

Bond, Stephen. 2012. "Assessment of the Potential Impact of the Resubmitted Outline Planning Application Relating to the Liverpool Waters Master Plan on Outstanding Universal Value at Liverpool Maritime Mercantile WHS." London: English Heritage.

Council of Europe. 1975. European Charter of the Architectural Heritage. Amsterdam: Council of Europe. http://www.icomos.org/en/charters-and-texts/179articles-en-francais/ressources/charters-andstandards/170-european-charter-of-the-architecturalheritage

De Figueiredo, P. 2011. "Liverpool Waters Heritage Impact Assessment: Assessment of Potential Effects on the Liverpool World Heritage Site." Liverpool Waters (Peel Holdings), Liverpool.

EPA (Environmental Protection Agency). 1992. "The Guardian: Origins of the EPA.” Accessed 16 December 2018. https://archive.epa.gov/epa/aboutepa/guardianorigins-epa.html

Erder, Cevat. 1986. "English Translation of the 1933 Athens Charter." In Our Architectural Heritage: From Consciousness to Conservation, edited by Cevat Erder, 219-220. Paris: UNESCO. http://unesdoc.unesco.org/ images/0007/000714/071433eo.pdf

European Commission. 2004. "SUIT: Guidance for the Environmental Assessment of the Impacts of Certain Plans, Programmes or Projects upon the Heritage Value of Historical Areas, in Order to Contribute to Their Long-term Sustainability." Accessed 16 December 2018. http://www.lema.ulg.ac.be/downloads/Suit.pdf

European Commission. 2014a. "Review of the Environmental Impact Assessment (EIA) Directive." Accessed 16 December 2018. http://ec.europa.eu/environment/ eia/review.htm

European Commission. 2014b. "Supporting Cultural Heritage." Accessed 16 December 2018. https://ec.europa. eu/culture/policy/culture-policies/cultural-heritage_en

European Union. 2010. “Toledo Declaration on Urban Development.” Accessed 16 December 2018. http:// ec.europa.eu/regional_policy/archive/newsroom/ pdf/201006_toledo_declaration_en.pdf

Gaillard, Bénédicte, and Dennis Rodwell. 2015. “A Failure of Process? Comprehending the Issues Fostering Heritage Conflict in Dresden Elbe Valley and LiverpoolMaritime Mercantile City World Heritage Sites." The Historic Environment: Policy and Practice 6 (1): 16-40.

Hinchliffe, J. and R. Burns. 2012. "Heritage Impact Assessment of Liverpool Waters on the Outstanding Universal Value of Liverpool-Maritime Mercantile City World Heritage Site." Liverpool: Liverpool City Council.

IAIA (International Association for Impact Assessment). 2009. "Vision, Mission, Values, Professional Code of Conduct, and Ethical Responsibilities." Accessed 16 December 2018. http://www.iaia.org/pdf/Code-of-Ethics.pdf 
ICOMOS. 1964. "International Charter for the Conservation and Restoration of Monuments and Sites." In International Charters for Conservation and Restoration, edited by Michael Petzet and John Ziesemer. 37-42. Paris: ICOMOS. http://openarchive.icomos.org/431/1/ Monuments_and_Sites_1_Charters.pdf

ICOMOS. 2004a. "The Athens Charter for the Restoration of Historic Monuments." In International Charters for Conservation and Restoration, edited by Michael Petzet and John Ziesemer. 31-36. Paris: ICOMOS. http://openarchive.icomos.org/431/1/Monuments_and_Sites_1_ Charters.pdf

ICOMOS. 2004b. "Dresden Elbe Valley (Advisory Body Evaluation)." Accessed 16 December 2018. http://whc. unesco.org/en/list/1156/documents/

ICOMOS. 2005. "Xi'an Declaration on the Conservation of the Setting of Heritage Structures, Sites and Areas." Accessed 16 December 2018. http://www.icomos.org/ charters/xian-declaration.pdf

ICOMOS. 2008. "Charter for the Interpretation and Presentation of Cultural Heritage Sites." Accessed 16 December 2018. https://www.icomos.org/charters/interpretation_e.pdf

ICOMOS. 2011a. "Guidance on Heritage Impact Assessments for Cultural World Heritage Properties.” Accessed 16 December 2018. https://www.icomos.org/ world_heritage/HIA_20110201.pdf

ICOMOS. 2011b. "On Heritage as a Driver of Development.” Accessed 16 December 2018. https://www. icomos.org/Paris2011/GA2011_Declaration_de_Paris_ EN_20120109.pdf

ICOMOS. 2015. "HIA Summary Report on Heritage Impact Assessment: Management of Major Projects in or near World Heritage Properties. Fact Finding and Data Collecting Study."

ICOMOS. 2017. "Cultural Heritage, the UN Sustainable Development Goals, and the New Urban Agenda." accessed 16 December 2018. http://www.usicomos.org/ wp-content/uploads/2016/05/Final-Concept-Note.pdf

Jokilehto, Jukka. 1999. "ICCROM Integrated Territorial and Urban Conservation, ITUC, Programme - Phase I (1994-1998) Summary Report." Accessed 16 December 2018. http://cif.icomos.org/pdf_docs/Documents\%20 on\%20line/ITUC_report_2-99.pdf

Le Corbusier. 1955. La Charte d'Athènes. Éditions de Minuit, Paris (original French text of the Charter).

Le Corbusier. 1973. Athens Charter (English translation of the 1933 Charter). New York: Grossman. https:// modernistarchitecture.wordpress.com/2010/11/03/ ciam \% E 2\% $80 \% 99$ s- \% E2\% $80 \% 9$ Cthe-athenscharter\%E2\%80\%9D-1933/

Liverpool City Council. 2003. Nomination of LiverpoolMaritime Mercantile City for Inscription on the World Heritage List. Liverpool: Liverpool City Council.

McHarg, Ian. 1969. Design with Nature. New York: Natural History Press.

Partidário, Maria Rosário. 2005. “The Contribution of Strategic Impact Assessment to Planning Evaluation.” In Beyond Benefit Cost Analysis-Accounting for NonMarket Values in Planning, edited in Miller, D. and Patassini, D, 151-162. Farnham: Ashgate Publishing.

Patiwael, Patrick R., Groote Peter and Vanclay Frank. 2018. "Improving Heritage Impact Assessment: An Analytical Critique of the ICOMOS Guidelines." International Journal of Heritage Studies.

Québec Government. 2006. “The Sustainable Development Act.” Accessed 16 December 2018. http://www.mddelcc.gouv.qc.ca/developpement/loi_en.htm

Ringbeck, Birgitt, and Mechtild Rössler. 2011. "Between International Obligations and Local Politics: The Case of the Dresden Elbe Valley under the 1972 World Heritage Convention.” Denkmalschutz und Stadtentwicklung. Informationen zur Raumentwicklung 3 (4): 205211.

Ripp, Matthias, and Dennis Rodwell. 2015. “The Geography of Urban Heritage." The Historic Environment: Policy and Practice 6 (3): 240-276.

Ripp, Matthias, and Dennis Rodwell. 2016. "The Governance of Urban Heritage." The Historic Environment: Policy and Practice 7 (1): 81-108.

Rodwell, Dennis. 2014. "Negative Impacts of World Heritage Branding: Liverpool-An Unfolding Tragedy?" In Between Dream and Reality: Debating the Impact of World Heritage Listing. Primitive Tider Special Edition 2014, edited by Hølleland, H. and S. Solheim, 19-34. Oslo: Reprosentralen.

Rodwell, Dennis. 2015. "Liverpool: Heritage and Development-Bridging the Gap?" In Industrial Heritage Sites in Transformation: Clash of Discourses, edited by Heike Oevermann and Harald A. Mieg, 29-46. New York: Routledge.

Sheate, William R, and Maria R. Partidário. 2010. "Strategic Approaches and Assessment Techniques: Potential for Knowledge Brokerage towards Sustainability." Environmental Impact Assessment Review 30 (4): 278-288.

Tomaszewski, Andrzej. 2005. "Intellectual Context of Monuments and Sites in Their Setting." Accessed 16 December 2018. http://openarchive.icomos. 
org/300/1/1-30.pdf

UNESCO. 1972. "Convention Concerning the World Cultural and Natural Heritage." Accessed 16 December 2018. https://whc.unesco.org/archive/convention-en. pdf

UNESCO. 1976. "Recommendation concerning the Safeguarding and Contemporary Role of Historic Areas." Accessed 16 December 2018. http://portal.unesco. org/en/ev.php-URL_ID $=13133 \& U R L \_D O=D O \_$ TOPIC\&URL_SECTION=201.html

UNESCO. 2005. "Vienna Memorandum on World Heritage and Contemporary Architecture-Managing the Historic Urban Landscape." Accessed 16 December 2018. http://whc.unesco.org/uploads/activities/documents/activity-47-2.pdf

UNESCO. 2006. "Mission Report: Liverpool-Maritime Mercantile City (United Kingdom) (1150) 18-20 October 2006." Accessed 16 December 2018. http://whc. unesco.org/en/list/1150/documents/

UNESCO. 2008a. "Decision: 32 COM 7B.129 Trends in the State of Conservation of World Heritage Sites." Accessed 16 December 2018. http://whc.unesco.org/en/ decisions/1736

UNESCO. 2008b. "World Heritage Committee Document WHC-08/32.COM/11E Reflection on the Preparation of the Next Cycle of Periodic Reporting." Accessed 16 December 2018. http://whc.unesco.org/archive/2008/ whc08-32com-11e.pdf

UNESCO. 2009. "Decision: 33 COM 7B.124 Historic Areas of Istanbul (Turkey).” Accessed 16 December 2018. http://whc.unesco.org/en/list/356/documents/

UNESCO. 2011. "Recommendation on the Historic Urban Landscape." Accessed 16 December 2018. http://portal. unesco.org/en/ev.php-URL_ID $=48857 \% 26 \mathrm{URL}_{\text {- }}$ DO=DO_TOPIC\%26URL_SECTION $=201 . \mathrm{html}$

UNESCO. 2016. Culture: Urban Future-Global Report on Culture for Sustainable Urban Development. Paris: UNESCO. http://unesdoc.unesco.org/ images/0024/002462/246291E.pdf

UNESCO. 2017. "Decision: 41 COM 7A.22 LiverpoolMaritime Mercantile City.” Accessed 16 December 2018. http://whc.unesco.org/en/decisions/6968

UNISDR. 2015. "Sendai Framework for Disaster Risk Reduction 2015-2030.” Accessed 16 December 2018. http://www.unisdr.org/files/43291_sendaiframeworkfordrren.pdf

UNISDR. 2017a. "How to Make Cities More Resilient: A Handbook for Local Government Leaders-A Contribution to the Global Campaign 2010-2020 'My City is
Getting Ready!'” Accessed 16 December 2018. https:// www.unisdr.org/campaign/resilientcities/assets/documents/guidelines/Handbook\%20For\%20Local\%20 Government\%20Leaders_WEB_May\%202017.pdf

UNISDR. 2017b. "The Ten Essentials for Making Cities Resilient." Accessed 16 December 2018. http://www. unisdr.org/files/26462_13.tenessentialschecklist.pdf

United Nations. 1972. "Declaration of the United Nations Conference on the Human Environment." Accessed 16 December 2018. http://www.un-documents.net/unchedec.htm

United Nations. 2016a. "New Urban Agenda adopted at Habitat III." Accessed 16 December 2018. https://unhabitat.org/new-urban-agenda-adopted-at-habitat-iii/

United Nations. 2016b "The Sustainable Development Agenda.” Accessed 16 December 2018. http://www. un.org/sustainabledevelopment/development-agenda/

United Nations. 2017. "Framework Convention on Climate Change.” Accessed 16 December 2018. http://unfccc. int/2860.php

URBACT. 2012. "HerO Results." Accessed 16 December 2018. http://urbact.eu/hero

WCED (World Commission on Environment and Development). 1987. Our Common Future. Oxford: Oxford University Press. http://www.un-documents. net/our-common-future.pdf

WHITRAP (World Heritage Institute of Training and Research for the Asia and the Pacific Region under the Auspices of UNECSO). 2012. "Heritage Impact Assessments, Training Workshop Report.” 